\title{
NATO PO LETU 2014 \\ NAZAJ H KORENINAM ALI NAPREJ \\ V PRIHODNOST?
}

\section{NATO AFTER 2014 \\ BACK TO THE ROOTS OR FORWARD TOWARDS THE FUTURE?}

Povzetek Naslov kljub vprašaju in možnosti poenostavljenega razumevanja ne predstavlja nujno vprašanja o prihodnosti razvoja zavezništva. Nazaj in naprej ne pomenita dveh smeri, temveč bolj združevanje naučenih lekcij in poudarjanje veznega tkiva, ki je Nato skozi zgodovino ohranjalo tako močno, ter opremljanje tega zdravega jedra z mehanizmi, ki nas bodo še naprej ščitili pred celotnim spektrom groženj. Pred tistimi, ki jih poznamo, tistimi, ki jih lahko predvidevamo, ter nekako tudi pred tistimi, ki jih ne moremo predvideti. Pri zadnjih je ključna beseda prilagodljivost. V takšnem prikazu lahko prepoznamo daljnovidnost zavezniškega koncepta iz leta 2010, ki kljub pretresom v Vzhodni Evropi in na Bližnjem vzhodu ter s tem povezanim povečanim občutkom ogroženosti v nekaterih zaveznicah ostaja temeljni smerokaz organizaciji tudi za prihodnja leta.

Vračanje h koreninam pomeni zagotavljanje prepričljive pripravljenosti na kolektivno obrambo, usmeritev v prihodnost pa možnost uporabe zmogljivosti za delovanje pred spektrom različnih groženj in izvajanje drugih temeljnih nalog zavezništva. Za zagotavljanje verodostojnosti organizacije ni nujna revolucija, temveč preprosta izpolnitev preteklih zavez za zagotavljanje zmogljivosti. Prav s tem so imele članice veliko težav in ravno njihova počasnost je imela/in ima negativne posledice na zavezniško kredibilnost. S tega vidika je lahko rusko-ukrajinska dinamika samo priložnost za obrambne sisteme, da opozorijo politične elite na pomen obrambe in dejstvo, da ta stane.

Ključne Nato, zasedanje vrha, Strateški koncept, mednarodno varnostno okolje, besede transformacija, kolektivna obramba, partnerstva.

Abstract Question in the title "Back to the Roots or towards the Future?" is not necessary a dilemma regarding the future of the Alliance. It is more about the necessary combination of both. The need to tie together the lessons learned, while strengthening the bonds that have been underpinning NATO throughout its history, and reinforcing 
the strong core of the Alliance with the mechanisms that are going to provide the necessary protection against the full spectrum of future threats. Threats that are known, the ones we can predict and those that are not yet foreseen. The starting point for the latter is flexibility. With this in mind we can clearly recognise the value of the 2010 Strategic Concept, which remains the guiding principle for the Alliance despite the events in Eastern Europe and Middle East and the increased security threats felt by some Allies.

Going back to the roots means a credible preparedness for collective defence, while going forward to the future signifies the importance of being able to use the capabilities to engage in the whole spectrum of possible missions and core tasks as indicated in the Strategic Concept. There is no need for the revolution to ensure the credibility of the Alliance, but there is a 'simple' demand to implement the commitments given in the past regarding the development of capabilities. This has been a challenge for many Allies, which has had/has already negative implications for the Alliance's credibility. In light of this the crisis in Ukraine can also be an opportunity for the national defence establishments to convince the political elites that defence matters and that there are costs associated with it.

\section{Key words NATO, Summit, Strategic Concept, international security environment, transformation, collective defence, partnership.}

Uvod Če so se mnogi poznavalci leta 2010 ob sprejetju novega Strateškega koncepta Nata spraševali o relevantnosti zavezništva in pomenu obrambe, so danes ti glasovi precej tišji in bolj osamljeni. ${ }^{1}$ Evroatlantsko varnostno okolje, predvsem zaznavanje njegove stabilnosti, se je leta 2014 nedvomno spremenilo. Rusko delovanje v Ukrajini in posledična panika $\mathrm{v}$ nekaterih vzhodnih zaveznicah nas nekako ponovno vodijo v prelomnico, saj se Nato po eni strani vrača h koreninam, po drugi pa pomen organizacije kot politično-obrambnega zavezništva dodatno postaja pomembnejši in prepoznavnejši. Varnost in obramba sta ponovno popularni.

Tudi brez zadnjih nasilnih sprememb mej na vzhodu stare celine je bilo zavezništvo na tisti stopnji razvoja, ko bi moralo zaradi različnih dejavnikov ponovno uravnotežiti svojo držo in prihodnje prednostne naloge. Operacija Nata v Afganistanu (International Security Assistance Force - Isaf) se zaključuje in z njo tudi precej zahtevno obdobje v zgodovini organizacije. Še pred kratkim je bil poglavitni izziv, kako preprečiti, da se po močnem in finančno zahtevnem operativnem tempu odpovemo skušnjavi, da se obramba in z njo povezni stroški poskušajo potisniti na stranski tir. Takšen razvoj dogodkov bi povečal nevarnost in verjetnost močnejšega razkoraka med Evropo in ZDA. Temu, vsaj njegovim političnim vidikom, smo se tudi na račun zadnje varnostne krize trenutno izognili, čeprav ostaja nevarnost, da bi različni pogledi na ostrino reševanja krize lahko ponovno izpostavili različne ocene in ambicije med obema stranema Atlantika. Konec planskega cikla Natovega procesa obrambnega planiranja junija 2014 (NATO Defence Planning Process

Glej Lampret, Novak, 2010. 
- NDPP) podaja zelo reprezentativen presek stanja po razpoložljivosti posameznih zmogljivostih ter jasno ocenjuje primanjkljaje in s tem povezana tveganja glede na zastavljeno raven ambicij zavezništva. Konec koledarskega leta se bo v Natu sprožil nov planski cikel s pripravo novih Političnih smernic, ki bodo temeljile na skupno sprejeti oceni varnostnega okolja in predvsem ponovno opredelile ali potrdile zavezniško raven ambicij delovanja (Level of Ambition).

Dinamika, povezana z Ukrajino, je v cikel zavezniškega načrtovanja pripeljala nekaj novega, predvsem ponoven razmislek o zavezniški obrambni drži in njeni geografski uravnoteženosti. Prav tako bo politično verjetno težko govoriti o zmanjševanju skupnih ambicij, čeprav so bile pred prenosom suverenosti nad Krimom nekatere zaveznice do tega razmeroma odprte. V prihodnjih razpravah bo vsekakor treba upoštevati finančne omejitve, saj se bo brez merljivega napredka na tem področju okrepila nevarnost, da bi vse ostalo pri besedah. Prelomnico pri denarju naj bi prineslo ravno vrhunsko srečanje Nata v Walesu. V mesecih priprav na ta dogodek se stopnjujejo pritiski na evropske zaveznice, da končno preidejo od retorike h konkretnim dejanjem. Pritiski oziroma bolje rečeno jasna pričakovanja so sicer razumljiva, saj izhajajo tako iz ameriške najave prihodnje osredotočenosti na azijsko-pacifiško območje kot tudi iz spremenjenega varnostnega okolja, kar je v sedanjem trenutku mogoče najpomembnejši element.

Čeprav ne pričakujemo večjega odklona od smeri razvoja, ki si jo je Nato začrtal v Strateškem konceptu leta 2010, vseeno ne moremo spregledati pomena in posledic, ki jih prinašajo nedavna ruska dejanja. Mehanizmi, ki jih ima zavezništvo na voljo, njegovo poslanstvo in naloge, se ne bodo bistveno spreminjali. Spremenila pa se bo obrambna drža zavezništva, ki bo izpopolnjevala izkazovanje solidarnosti, notranjo kohezijo ter temeljna načela in vrednote zavezništva. Nato se je na ukrajinsko krizo že odzval in tudi planska skupnost te krize preprosto ne more spregledati. Zagotovo bo v naslednjem srednjeročnem obdobju eden od scenarijev uporabe zavezniških sil vključeval konvencionalni spopad s tehnološko primerljivim zaveznikom, vsaj na posameznih področjih. To bo zahtevalo ohranjanje nekaterih zmogljivosti, ki so jih posamezne zaveznice samovoljno precej opuščale (oklepni manever, helikopterji, minolovci), in nedvomno povečanje pogostosti in zahtevnosti vaj z vključevanjem in prepletanjem vseh treh zvrsti oboroženih sil. Ohranjanje kredibilnosti od zaveznic zahteva, da na prihodnjem vrhunskem srečanju strnejo vrste, nakažejo smer reševanja in vloge Nata ter predvsem svoje zaveze tudi uresničijo. To bo seveda zahtevalo ustrezne vire, za katere je ključna tudi javna podpora. Tako se bo vrhunskega srečanja v Walesu treba lotiti z različnih vidikov, gotovo pa bo javna diplomacija ena izmed tistih, pri katerih zavezništvo preprosto ne sme zgrešiti.

Aktualna varnostna dinamika kaže tudi na dejstvo, da potreba po sposobnosti za izvajanje kolektivne obrambe ni ostanek hladne vojne, temveč temelj prihodnje kohezivnosti zavezništva. Občutek neposredne ogroženosti v nekaterih zaveznicah se je precej povečal, zato je treba, predvsem zaradi ohranjanja politične enotnosti 
organizacije, prepoznavno okrepiti nekatere segmente obrambne pripravljenosti, ki so bili v preteklih dveh desetletjih zapostavljeni.

To je zelo tesno povezano z odgovornostjo vseh zaveznic, da zagotovijo svoje obrambne zmogljivosti in prispevajo $\mathrm{k}$ zavezniškim naporom pri uresničevanju treh temeljnih nalog - kolektivne obrambe, kriznega upravljanja in sodelovanja s partnerji. Za povečanje verodostojnosti obrambne drže bo račun razdeljen med vseh 28 zaveznic, kljub različnim nacionalnim ocenam varnostne ogroženosti zaradi ruskih dejanj v Ukrajini. To bo svojevrsten izziv.

Članek se opira na dosežke Nata, ki letos praznuje 65 let, pri čemer se dotakne posameznih ključnih tem, kot so operacije, transformacija, zmogljivosti, viri, reforme in partnerstva. Prav tako poskuša prikazati zapletenost vprašanj in ključne smernice nadaljnjega razvoja tega edinstvenega politično-vojaškega čezatlantskega zavezništva, kot ga bodo na svojem zasedanju potrdili predsedniki držav in vlad septembra 2014 v Walesu. Sklep ponuja sintezo razmišljanj in vodi bralca do odgovorov na vprašanje o prihodnosti Nata.

Članek temelji na osebnih izkušnjah avtorjev, ki neposredno spremljata razvoj organizacije še iz časov pred polnopravnim slovenskim članstvom in sta bila več let tudi neposredno vključena $\mathrm{v}$ oblikovanje nacionalnih vodil aktualne transformacije Nata. Opira se predvsem na analize dokumentov Nata, ki niso označeni s stopnjo tajnosti, nastopov visokih predstavnikov te organizacije in sekundarnih virov, ki omogočajo celovitejše razumevanje obravnavane tematike.

\section{NATO DANES}

\subsection{Spremenjeno varnostno okolje}

Konec operacije Isaf v Afganistanu leta 2014 sam po sebi daje priložnost za strateški razmislek in preusmerjanje pozornosti zavezništva na širok seznam morebitnih varnostnih groženj. Rusko-ukrajinska kriza je samo zadnji dokaz, da je prihodnost nepredvidljiva, globalna varnostna situacija kompleksna in med seboj prepletena, zavezništvo pa obdano z nestabilnostmi, ki prihajajo iz Ukrajine, Sirije, Iraka in Sahela (gen. Bartels, 21. maj 2014).

Kljub omenjenim spremembam varnostnega okolja, ki so jih zaznamovale predvsem ruske akcije v Ukrajini, ostajajo temelji Nata trdni in njegova vloga nepogrešljiva. Strateški koncept Nata oziroma temeljna strateška vizija prihodnosti zavezništva je že leta 2010 zajela kompleksnost sodobnega varnostnega okolja. Koncept izpostavlja, da je možnost konvencionalnega napada na ozemlje Nata majhna, vendar je ne smemo zanemariti. Hkrati pa so vključene tudi druge sodobne grožnje, kot so na primer širjenje orožja za množično uničevanje, terorizem, nestabilnosti in konflikti zunaj zavezniških mej, kibernetske grožnje, grožnje energetski varnosti ter vplivi razvoja tehnologije in klimatskih sprememb (Strateški koncept, 2010). 
V obdobju globalizacije, intenzivne medsebojne odvisnosti in transnacionalnih varnostnih izzivov obsega varnostno okolje širok in nenehno spreminjajoč se seznam izzivov zavezniškemu ozemlju in prebivalstvu, zato Strateški koncept izpostavlja, da mora biti zavezništvo sposobno uresničevati tri glavne naloge - kolektivno obrambo, krizno upravljanje in skrbeti za kooperativno varnost. Njegov temeljni namen pa ostaja varovanje svobode in varnosti vseh članic tako s političnimi kot z vojaškimi sredstvi (Strateški koncept, 2010).

Če krize v Ukrajini ne bi bilo, bi se zavezništvo z naslednjim vrhom verjetno usmerilo $\mathrm{v}$ življenje po Isafu, $\mathrm{v}$ transformacijo, ki bi izhajala predvsem iz predpostavke omejenih finančnih virov, in v nadaljevanje optimizacije obrambnih struktur. Številni mehanizmi, pobude in načrti za prihodnost, po katerih je Nato deloval na podlagi odločitev, sprejetih v Lizboni in Chicagu, kljub krizi ostajajo relevantni, vendar jih bo treba na novo uravnotežiti glede na varnostno dinamiko na Vzhodu. Če je bilo še pred nekaj meseci v ospredju razmišljanje o zmanjševanju sodelovanja v operacijah in o krepitvi pripravljenosti (from deployed to prepared) ${ }^{2}$, se Nato zdaj usmerja h krepitvi pripravljenosti v smislu večje prilagodljivosti in hitrejše odzivnosti, ki vključuje tako zaustavitev zmanjševanja obrambnih izdatkov kot tudi sprejemanje ukrepov varnostnih zagotovil za vzhodne zaveznice, vključno s povečanjem odzivnosti zavezniških sil in njihove prisotnosti na vzhodnih mejah zavezništva.

Ta prizadevanja so se okrepila predvsem kot posledica ruskega zatekanja $\mathrm{k}$ bliskovitim vojaškim vajam, kibernetskim aktivnostim in prikritim operacijam za doseganje njihovih ciljev (SACEUR gen. Breedlove, 22. maj 2014). Pristop označujemo s terminom hibridno vojskovanje. S takšnimi ukrepi v Ukrajini je Rusija v imenu zaščite rusko govorečih manjšin temeljito posegla $\mathrm{v}$ mednarodni red, ki se je oblikoval po koncu hladne vojne oziroma že po koncu druge svetovne vojne, vključno s kršenjem načel Ustanovne listine Organizacije združenih narodov, kot sta načeli suverenosti in ozemeljske celovitosti. Z uporabo vojaških sredstev za doseganje svojih interesov, s spreminjanjem mej v Evropi, z nespoštovanjem mednarodnega prava, vključno z Ustanovno listino Sveta Nato-Rusija, je postavila pod vprašaj vizijo svobodne in mirne Evrope (Vershbow, 1. maj 2014, in generalni sekretar (GS) Nata Rasmussen, 1. april 2014).

\subsection{Posledice spremenjenega varnostnega okolja}

Dojemanje grožnje, ki naj bi jo predstavljala Rusija, se je v očeh baltskih držav, Poljske, Romunije, Bolgarije pa tudi Češke in na trenutke Slovaške, ki so že prej veliko pozornosti namenjale politiki in ukrepom odvračanja, vključno z nestrateškim jedrskim orožjem v Evropi, s krizo v Ukrajini samo še okrepilo (Kulesa, ur., 2012; Larrabee in drugi, 2012, str. 75-76; Asmus in drugi, 2010). V ospredje je znova prišla kolektivna obramba, prva med temeljnimi nalogami Nata, kot jo predstavljajo omenjene zaveznice. V takšnem varnostnem okolju je ključno ohranjanje solidarnosti,

2 Glej Münchenska varnostna konferenca, 2013. 
koherentnosti in enotnosti vseh 28 zaveznic v Natu. Po ugibanjih o upokojitvi zavezništva se je po ocenah nekaterih pojavil nov raison d'être oziroma v ospredje je prišel njegov stari raison d'être (Vershbow, 1. maj 2014).

Največja odgovornost zavezništva tako še vedno ostaja 5. člen Severnoatlantskega sporazuma oziroma zaščita in obramba ozemlja ter prebivalstva pred zunanjimi napadi, ki je za zavezništvo ključno varnostno zagotovilo, na podlagi katerega zaveznice lahko računajo na ustrezen odziv, če bi bile ogrožene. Nepogrešljiva stebra zavezniške strategije ohranjanja varnosti članic ostajata odvračanje, ki temelji na ustrezni kombinaciji jedrskih in konvencionalnih sil, ter koncept nedeljivosti zavezniške varnosti.

Odzivanje na krizo v Ukrajini je potrdilo tudi pomen Nata kot pomembnega čezatlantskega foruma za varnostna politična posvetovanja o vseh zadevah, ki se nanašajo na ozemeljsko integriteto, politično neodvisnost in varnost članic, kot to določa 4. člen Severnoatlantskega sporazuma. Katera koli zaveznica lahko kadar koli sproži postopek, ki z delitvijo informacij, izmenjavo mnenj in, če je treba, $\mathrm{z}$ oblikovanjem skupnega odzivanja prispeva $\mathrm{k}$ boljšemu razumevanju in učinkovitejšemu upravljanju kriz. Ravno to je storila Poljska 3. marca 2014 zaradi razmer v Ukrajini (Nato, 4. marec 2014), kar je prebudilo celotno zavezništvo in vodi v nove odločitve, povezane s prihodnjo držo zavezništva, ki bodo potrjene na septembrskem vrhu. ${ }^{3}$

\subsubsection{Viri}

Kolektivna obramba se zagotavlja s kolektivno odgovornostjo. V zavezništvu ima vsaka zaveznica svojo vlogo in vsaka po svojih močeh prispeva h kolektivni odgovornosti, kar se imenuje solidarnost. Članstvo v Natu ni le privilegij, temveč tudi obveznost (GS Nata, 9. maj 2014). Če je bil kdaj dvom o pomenu obrambe, naj bi ga kriza v Ukrajini dokončno pregnala, meni generalni sekretar Nata in potrjujejo tudi zaveznice z aktivnim sodelovanjem pri odzivanju na krizo v Ukrajini (GS Nata, 15. maj 2014, in Nato, 3. junij 2014 a).

Tudi ameriški predsednik Obama je med svojim obiskom Bruslja izpostavil, da morajo vse zaveznice prispevati svoj delež, ki izhaja iz članstva v zavezništvu, tako da pokažejo politično voljo za investiranje v kolektivno obrambo in za razvoj zmogljivosti za zagotavljanje mednarodnega miru in varnosti. Varnost ni zastonj in vse zaveznice morajo pokazati, da so pripravljene zagotoviti vire za zmogljivosti, osebje, usposabljanje, skratka za vse, kar je nujno za zagotovitev verodostojne in učinkovite odvračalne drže Nata (Obama, 26. marec 2014 a, in Obama, 26. marec 2014 b).

\footnotetext{
Do danes je bil 4. člen uporabljen samo štirikrat. Pred Poljsko je leta 2012 Turčija zaradi razmer v Siriji dvakrat zaprosila za sklic Severnoatlantskega sveta (NAC) na podlagi 4. člena, kar je privedlo do namestitve zavezniških raket Patriot na turškem ozemlju, in še leta 2003 zaradi razmer v Iraku (Nato, 4. marec 2014).
} 
Ti pozivi nikakor niso nekaj novega, sta se pa precej okrepila njihova intenzivnost in pomen. Z rusko pripravljenostjo, da posreduje z vojaškimi sredstvi v drugi državi, in v luči dejstva, da je Rusija v zadnjih petih letih povečala svoje obrambne izdatke za 10 odstotkov na leto, medtem ko so zaveznice drastično zmanjšale svoje obrambne proračune (nekatere tudi za več kot 40 odstotkov) ${ }^{4}$ in delovale ob predpostavki, da je Rusija strateški partner in ne neposredna grožnja za zavezništvo, je postalo jasno, da morajo članice Nata spremeniti trend obrambnih izdatkov in znova preusmeriti pozornost na ključne naloge Nata, še posebno kolektivno obrambo (GS Nata, 19. maj 2014 in 15. maj 2014).

Ruske akcije na Krimu in vzhodu Ukrajine so prebudile zavezništvo. Kot je dejal generalni sekretar Nata, je Rusija s tem nenamerno prispevala k utrditvi čezatlantskega zavezništva. Utrdilo se je prepričanje, da varnost in stabilnost nista samoumevni. Vendar so izzivi pred zaveznicami ogromni. Zaveza, ki naj bi ji zaveznice na področju obrambnih izdatkov sledile, se v glavnem nanaša na zagotavljanje dveh odstotkov BDP za obrambo. Prvi pričakovan korak danes je, da tiste članice, ki tega še niso naredile, ustavijo padec obrambnih izdatkov in jih začnejo postopno in merljivo zviševati. Kolektivna obramba je predmet investicij in vprašanje prihodnjih prioritet, predvsem tistih, usmerjenih v cilje Nata. ${ }^{5}$ Pri tem je treba utrjevati čezatlantsko vez, z jasno zavezanostjo tako Evrope kot tudi ZDA (GS Nato, 8. april 2014). Ključno pri tem je tudi sodelovanje med Natom in EU, s krepitvijo evropske obrambe se namreč krepi tudi Nato. Moč zavezništva se, danes še bolj kot prej, skriva v solidarnosti in skupnem delovanju.

\subsubsection{Ukrepi varnostnih zagotovil}

Zunanji ministri Nata so 1. aprila 2014 kot neposreden odziv na krizo v Ukrajini obnovili zavezo o krepitvi kolektivne obrambe zavezništva, potrdili pripravljenost pomagati Ukrajini in prekinili praktično sodelovanje z Rusijo (Nato, 1. april 2014, SACEUR gen. Breedlove, 22. maj 2014). Kot naslednji korak je zavezništvo 16. aprila 2014 sprejelo paket vojaških ukrepov oziroma varnostnih zagotovil, ki naj bi pomirila skrbi predvsem vzhodnih zaveznic z okrepitvijo prisotnosti v zraku (izvidniška letala AWACS, nadzor zračnega prostora oziroma Air Policing) in na morju ter s povečano intenzivnostjo usposabljanj in vojaških vaj (Zavezniško združeno poveljstvo sil Brunssum, 27. maj 2014). V duhu solidarnosti so se odzvale vse zaveznice po načelu vsi za enega in pokazale zavezanost $\mathrm{k}$ temeljnim načelom kolektivne obrambe (Nato, 3. junij 2014 b).

V širšem smislu pa se mora zavezništvo kot odgovor na krizo v Ukrajini in na izražene skrbi nekaterih zaveznic Nata ter upoštevajoč tudi druge varnostne grožnje in izzive v prihodnje usmeriti predvsem na tri elemente: krepitev pripravljenosti,

\footnotetext{
Glede obrambnih izdatkov članic Nata glej tudi Nato, 24. februar 2014, in Larrabee in drugi, 2012, str. 1 - 3.

Številne zaveznice, kot so Litva, Latvija in Romunija, so se že odzvale z najavami o zviševanju investicij v obrambo. Poljska je že blizu mejniku 2 odstotka BDP, Estonija pa je že primer zgledne zaveznice (GS Nata, 15. maj 2014). Kako se bo ta tok razvijal naprej, bo pokazal že septembrski vrh Nata.
} 
investicije v obrambo in aktivno ohranjanje čezatlantske vezi, kar naj bi bile tudi osrednje teme vrha v Walesu.

Velik del odgovora na nedavna ruska dejanja in z njimi povezane izzive ter hkrati tudi širši odgovor na aktualno varnostno okolje bosta vključena $\mathrm{v}$ tako imenovani Akcijski načrt pripravljenosti, kot ga je poimenoval GS Nata, ki ga bodo potrdili predsedniki držav in vlad na vrhu. Začetne zamisli so vključevale pregled razvoja sil za obrambo in odvračanje oziroma pregled odzivnih sil Nata (NATO Response Forces - NRF), namenjenih zagotavljanju hitrejše odzivnosti, pregled ocene ogrožanja, izmenjavo obveščevalnih podatkov, zgodnje opozarjanje in krizno odzivanje. Pod drobnogledom je tudi pobuda povezanih sil (Connected Forces Initiative-CFI), s katero naj bi zagotavljali pogostejše, zahtevnejše in vidnejše vaje, z večjim poudarkom predvsem na 5. členu Severnoatlantskega sporazuma. Ti načrti imajo svojo ceno, vendar so stroški (ne)varnosti lahko bistveno večji, kar znova vodi do ugotovitve, da brez ustreznega investiranja ne more biti kolektivne varnosti (GS Nata, 8. april 2014, in 15. maj 2014).

\subsection{Zapuščina sedanjega generalnega sekretarja Nata}

Generalni sekretar Nata Anders Fogh Rasmussen se je v svojem mandatu zelo ambiciozno lotil obsežnih reform organizacije in posredoval številne pobude, ki naj bi usmerjale zavezništvo pri njegovi transformaciji v obdobju omejenih finančnih virov, utrujenosti od sodelovanja $\mathrm{v}$ operaciji Isaf in precej velike ravnodušnosti javnosti. Njegova agenda je bila pripraviti zavezništvo za 21. stoletje (NSC Magazine, junij/ september 2014, str. 5).

\subsubsection{Natove reforme}

Od ustanovitve leta 1949 do danes se je Nato že večkrat uspešno prilagodil spremembam varnostnega okolja. Tudi aktualni strateški koncept, ki je bil sprejet pod vodstvom Rasmussena, izpostavlja potrebo po nenehni reformi, ki naj bi z izboljšanjem struktur in delovnih metod sedeža Nata, njegovih agencij, poveljniške strukture in upravljanja virov vodila v večjo učinkovitost organizacijskega delovanja, prilagodljivost in odzivnost odločanja. Vrh v Lizboni leta 2010 je dal pomembne usmeritve za doseganje večje učinkovitosti (Deklaracija iz Lizbone), pri čemer je finančna vzdržnost postala gibalo in motiv glavnine sproženih reform. Jasno je bila prepoznana potreba, da mora organizacija nekako deliti usodo nacionalnih obrambnih sistemov in merljivo optimizirati svoja obseg in delovanje.

Reforma Natove poveljniške strukture je usmerjena $v$ doseganje manj številne, učinkovitejše in varčnejše strukture (6800 mest v miru) ob predpostavki, da bodo zaveznice v celoti popolnile to strukturo. Cilj naj bi bil dosežen do leta 2015. Reforma Natovega sedeža je po začetnem, bolj umetnem, zmanjšanju števila odborov usmerjena predvsem v ustrezno premeščanje delovnih mest znotraj mednarodnega sekretariata glede na prednostne naloge zavezništva, s katerim želi doseči optimizacijo razpoložljivih človeških virov. Podobno se zmanjšuje tudi število Natovih agencij in 
izboljšuje proces upravljanja virov, predvsem pri programiranju ter zagotavljanju preglednosti in odgovornosti (Polat, 6. april 2014).

$\mathrm{Na}$ vrhu v Walesu lahko ponovno pričakujemo, da bo poudarek na reformah in nadaljnjih usmeritvah predsednikov držav in vlad, ki bodo podlaga za prihodnje prilagajanje zavezništva spremenjenemu varnostnemu okolju, še posebno z vidika odzivanja na krizo v Ukrajini. Pri tem lahko v duhu zavezniške solidarnosti pričakujemo, da se ne bo več poudarjalo zategovanje pasu, temveč predvsem iskanje ustreznega ravnotežja med zagotavljanjem učinkovitosti in solidarnostjo. Zadnje predvsem v luči pomirjanja strahov in odganjanja dvomov v nekaterih vzhodnih zavezniških prestolnicah. Celo več, ker zaveznice počasi okrevajo po finančni krizi, se pričakuje, da bodo zaustavile nadaljnje reze, preusmerile trend obrambnih izdatkov in začele povečevati obrambne proračune.

\subsubsection{Transformacija Nata}

Prilagajanje spremembam mednarodnega varnostnega okolja in drugim realnostim (finančnim, političnim, socialnim) je torej inherenten del obstoja in prihodnosti Nata. Transformacija je proces, ki se nikoli ne konča. Prilagodljivost je ključno vodilo zavezništva, ki mora še naprej temeljiti na načelih in vrednotah, na katerih je bilo zavezništvo tudi vzpostavljeno.

S sprejetjem cilja Natove sile 2020 na vrhunskem srečanju v Chicagu leta 2012 so se zaveznice zavezale k ustvarjanju: »sodobnih, tesno povezanih sil, ki bodo ustrezno opremljene, usposobljene, izurjene, ki bodo imele ustrezno poveljniško strukturo ter bodo sposobne skupnega delovanja in sodelovanja s partnerji v vsakem okolju«. Sprejet je bil tudi tako imenovani obrambni paket zmogljivosti, ki se osredinja na ključna področja razvoja zmogljivosti, nujnih za uresničevanje cilja (Deklaracija o obrambnih zmogljivostih, Chicago, 2012).

Da bi dosegli večjo učinkovitost pri doseganju ambicij, je generalni sekretar Nata na münchenski varnostni konferenci v letih 2011 in 2012 zaporedoma predstavil dve pobudi - pametno obrambo (Smart Defence) in pobudo povezanih sil (Connected Forces Initiative - CFI), ki naj bi dopolnili proces razvoja zmogljivosti v okviru Natovega procesa obrambnega planiranja, ki po mnenju nekaterih ni več v celoti zagotavljal ustreznih rezultatov (op. ne zaradi procesa, temveč predvsem zaradi zmanjševanja obrambnih izdatkov in nezmožnosti izpolnjevanja obveznosti zaveznic). Pobudi temeljita na krepitvi večnacionalnega sodelovanja, tako med zaveznicami kot z drugimi partnerji, na poglobljeni ravni zaupanja in krepitve sposobnosti skupnega delovanja ter stalnega preverjanja in ohranjanja dosežene interoperabilnosti. Z vidika spremenjenega varnostnega okolja in finančnih izzivov so ju zaveznice sprejele kot edini mogoč modus operandi za prihodnost (Deklaracija o obrambnih zmogljivostih, Chicago, 2012).

Ohranjanje in izpopolnjevanje pridobljenih izkušenj, ki so jih zavezniške sile pridobile iz večdesetletnega sodelovanja $\mathrm{v}$ operacijah, stopnja povezljivosti in 
sposobnosti skupnega delovanja, tako med zaveznicami kot z drugimi partnerji, ki je enkratna prvina in moč zavezništva, so elementi, ki so, še posebno po koncu Isafa in ne nazadnje tudi z vidika odzivanja na dogodke v Ukrajini, postavili v ospredje predvsem pobudo povezanih sil.

Ustrezna usposabljanja in vaje so prepoznani kot eden temeljnih elementov vzpostavljanja večje odzivnosti zavezništva ter krepitve vidnosti obrambnih zmogljivosti. Oktobra 2013 so ministri za obrambo sprejeli odločitev o vaji visoke stopnje prepoznavnosti (high visibility exercise) leta 2015, ki bo vključila veliko kopenskih, pomorskih in zračnih sil, njene gostiteljice pa bodo Španija, Portugalska in Italija. Od leta 2016 bodo takšne vaje potekale redno, vključevale pa bodo urjenje za vse vrste zavezniških misij, tako operacije po 5. členu kot operacije zunaj tega člena. Pripravljen bo tudi nov koncept usposabljanja in vaj do leta 2020. Pobuda zahteva boljšo uporabo tehnologije za doseganje večje povezljivosti, na primer $\mathrm{z}$ uporabo mrežno povezljivih simulatorjev (Nato, 24. oktober 2013).

Gibalo pobude povezanih sil so Natove odzivne sile (NRF) in specialne sile (Special Operations Forces - SOF). NRF so hitro premestljive tehnološko napredne večnacionalne sile, ki združujejo kopenske, zračne in pomorske komponente ter specialne sile. Štejejo približno 13.000 pripadnikov (aktivni del t. i. Sile za takojšnje posredovanje (IRF)), ki jih zagotavljajo zaveznice po sistemu rotacij. Po letu 2014 naj bi Nato na temelju teh sil izpopolnjeval prihodnjo operativno pripravljenost in nadaljnjo transformacijo. V spremenjenem varnostnem okolju pričakujemo, da se bodo prav s temi silami krepili odzivnost in robustnost organizacije ter njen vojaški pečat. Povečujeta pa se tudi vloga in prepoznavnost specialnih sil in njihovega poveljstva, ki načrtuje in usklajuje zavezniške misije teh sil ter prispeva k izboljšanju sodelovanja in povezljivosti med njimi (Nato, 24. oktober 2013).

Poleg omenjenih pobud je v zavezništvu zaživela še ena, ki jo je najprej predstavila Nemčija in je usmerjena $\mathrm{v}$ krepitev skupnih evropskih naporov pri dolgoročni vzpostavitvi zmogljivosti, ki so prednostne za zavezništvo. Tako imenovani koncept vodilnih držav se osredotoča na skupine držav, ki se pod vodstvom vodilne države (za to vlogo so primerne le tiste zaveznice, ki imajo veliko zmogljivosti) prostovoljno združujejo za gradnjo celovitih sklopov zmogljivosti in sil. Trenutno Nemčija ustvarja skupino, ki bo usmerjena predvsem v tiste zmogljivosti, ki so bile na ravni zavezništva prepoznane kot prednostne, Velika Britanija pa oblikuje skupne ekspedicijske sile (GS Nata, 3. junij 2014). Kmalu naj bi sledile tudi nove najave podobnih skupin.

Večnacionalno sodelovanje in večnacionalne pobude so postali pomemben vidik gradnje zmogljivosti. Njihov namen je predvsem usmeriti in združiti napore za doseganje zastavljenih ciljev zmogljivosti in uresničevanje prednostnih nalog Nata, ki izhajajo iz Natovega procesa obrambnega planiranja. Kot izpostavlja tudi generalni sekretar Nata (15. maj 2014), lahko pomagajo krepiti nacionalne napore, vendar ne morejo nadomestiti ustreznih nacionalnih investicij. 
Transformacija Nata ne poteka zgolj na področju razvoja zmogljivosti, temveč v širšem sklopu zagotavljanja pripravljenosti na izzive 21. stoletja, kar vključuje tudi zagotavljanje pripravljenosti za odzivanje na vse zelo različne varnostne grožnje. Nato mora ohraniti sposobnost zagotavljanja obrambe in varnosti prebivalstva, kar, kot je zapisano Strateškem konceptu, vključuje tudi krepitev zmogljivosti za spopad s sodobnimi varnostmi izzivi, kot so kibernetske grožnje, piratstvo, terorizem in raketna obramba.

Področje, na katerem je Nato v zadnjih letih dosegel velik napredek, je kibernetska obramba. Ministri za obrambo so junija 2014 sprejeli okrepljeno politiko kibernetske obrambe, v katero so vključili napredek, ki je bil dosežen od leta 2011, ko sta bila sprejeta prvotna politika in njen akcijski načrt. Nova politika na podlagi načel nedeljive varnosti in solidarnosti umešča kibernetsko obrambo v okvir kolektivne obrambe in s tem 5. člena, kar je velik napredek v razmišljanju zavezništva in izraz pomena, ki ga pripisuje kibernetski obrambi. Vsebuje določila, ki se nanašajo na Natovo pomoč zaveznicam ob kibernetskem napadu in pri razvoju zmogljivosti. $\mathrm{V}$ duhu krepitve mednarodne varnosti se je zavezništvo zavezalo tudi h krepitvi partnerstev, še posebno z EU, in k sodelovanju z industrijo (GS Nata, 3. junij 2014, in Nato, 7. avgust 2014).

Zaveznice so se zelo ambiciozno lotile izziva z jasnimi zavezami k nadaljnji gradnji zmogljivosti za preprečevanje in odkrivanje kibernetskih napadov, obrambo pred njimi in okrevanje po njih (Strateški koncept, 2010). Nato je pri tem odgovoren za zaščito svojih omrežij, medtem ko so zaveznice odgovorne za razvoj svojih zmogljivosti kibernetske obrambe (prav tam). Tudi na tem področju so zaveznice vedno bolj pripravljene sodelovati v skupnih, večnacionalnih projektih. Razvitost zmogljivosti kibernetske obrambe je med zaveznicami trenutno še vedno precej različna, vendar so ravno zaradi načela zavezništvo je močno tako, kot je močan njegov najšibkejši člen primorane zagotoviti minimalne standarde zaščite in primerno raven nacionalne kibernetske obrambe.

\subsubsection{Partnerstva}

Kooperativna varnost, ki temelji na sodelovanju s partnerji, ostaja ena izmed treh temeljnih nalog Nata. Partnerstva so ključ do krepitve Natove pripravljenosti na vse izzive, kot si jo je zamislil generalni sekretar Rasmussen (NSC Magazine, junij/ september 2014, str. 9). Partnerska politika ima številne razsežnosti in obsega mrežo različnih partnerjev z evroatlantskega območja, iz Sredozemlja in zalivske regije ter tistih, ki spadajo med tako imenovana globalna partnerstva, vključeno je tudi sodelovanje s številnimi mednarodnimi organizacijami. Partnerji so v zadnjih dveh desetletjih s svojimi prispevki v zavezniške operacije in druge merljive napore pri skupnem spopadanju z varnostnimi izzivi večkrat dokazali svojo vrednost, konkretno potrditev pa je sodelovanje dobilo na vrhunskem srečanju v Lizboni leta 2010, ko je prišlo do odločitve za krepitev partnerskega sodelovanja, in leta 2011, ko je bila potrjena nova partnerska politika zavezništva (Nato, 31. marec 2014). 
Tako kot zaveznice so tudi partnerice, ki so organizacijo podpirale takrat, ko je bilo to najbolj pomembno, $\mathrm{z}$ aktivnim delovanjem $\mathrm{v}$ operacijah dosegle zavidljivo stopnjo interoperabilnosti. Z mehanizmi za krepitev zmogljivosti za operacije (Operational Capabilities Concept Programme) ima Natovo poveljstvo za operacije (SHAPE) na voljo mehanizme certifikacije prispevkov partnerskih držav skladno s standardi Nata. Spoštovanje teh vnaprej znanih meril in standardov, ki izhajajo iz krovne Natove politike izobraževanja, usposabljanja, vaj in evalvacije ter izvedbenih aktov, je dober temelj za delovanje in ohranjanje interoperabilnosti tudi v prihodnje. Prav tako je pomembno tudi sodelovanje v planskem mehanizmu za države članice Partnerstva za mir, imenovanem PARP (Partnership for Peace Planning and Review Process), ki se osredinja predvsem na delovanje zmogljivosti in je zelo podoben procesu, ki ga uporabljajo članice. K večji povezljivosti bodo gotovo prispevale tudi nove pobude, kot so pobuda povezanih sil, pametna obramba ter koncept vodilnih držav. Vrh bo ponudil priložnost Natu in partnerjem, da ponovno potrdijo zavezo, da se pripravljenost in zmogljivost skupnega delovanja ohranita tudi v prihodnje (Appathurai, 2014, str. 35 - 38).

Še več, s spremenjenim varnostnim okoljem in spremenjeno dinamiko sodelovanja v operacijah po Isafu ter z zadržanostjo zavezniških javnosti do podpore sodelovanju v operacijah velikega obsega zunaj ozemlja Nata se krepijo zmogljivosti zavezništva za usposabljanje lokalnih sil (defence capacity building) brez obsežne logistične prisotnosti na terenu (Brattberg, 2013, str. 19). To je že uveljavljena praksa delovanja zavezništva, vendar ima nov kakovostni vidik glede na aktualne spremembe mednarodnega varnostnega okolja. Takšne naloge obsegajo svetovanje, pomoč, podporo, usposabljanje in urjenje v sklopu reform obrambnega in varnostnega sektorja partnerskih in nepartnerskih držav. Zavezništvo si je s tega področja že nabralo številne izkušnje, zagotoviti pa je treba večjo odzivnost in boljšo uskladitev vseh naporov, tudi v odnosu do sodelovanja z drugimi mednarodnimi organizacijami, kot je izpostavljeno tudi v zavezniškem konceptu celostnega pristopa (Appathurai, 2014, str. 42). V prihodnje bi se ta pristop lahko uporabil v novih misijah v Afganistanu, Ukrajini in Libiji ter na številnih drugih območjih.

Poleg tega se je pri Ukrajini odprlo dodatno vprašanje o partnerstvih, ne le glede pričakovanj, ki jih lahko imajo partnerske države do Nata, temveč tudi v smislu politike odprtih vrat. Z odzivom Nata na ruski vdor v Ukrajino je postalo vsem jasno, da ostaja načelo kolektivne obrambe le za polnopravne članice in tu sprememb ne bo, čeprav bi si mogoče nekatere države želele drugače. Partnerjem ostajata na voljo Natova pomoč pri obrambnih reformah, modernizaciji obrambnih institucij, uveljavljanju integritete, preglednosti in odgovornosti ter krepitev sposobnosti partnerskih sil, da delujejo skupaj z zavezniškimi. Sodelovanje poteka tudi na civilno-kriznem področju, pri pomoči ob naravnih in drugih nesrečah, znanstvenem in tehnološkem sodelovanju ter spopadanju z novimi varnostnimi izzivi, kot sta terorizem in kibernetska obramba (DSG Vershbow, 13. maj 2014). 
Kljub temu ne smemo mimo dejstva, da se je politika odprtih vrat v zgodovini izkazala kot ena najuspešnejših politik, ki so prispevale k varnosti in miru v Evropi. Strateški koncept Nata je leta 2010 znova potrdil zavezanost k širitvi na evropske države, ki so sposobne prevzeti obveze, ki izhajajo iz članstva, in prispevati $\mathrm{k}$ evroatlantski varnosti. Proces še ni končan, se je pa z ukrajinsko-rusko krizo pojavila nova dinamika $v$ odnosu do držav, ki si prizadevajo za članstvo.

\section{NATO JUTRI}

Izzivi, s katerimi je bilo soočeno zavezništvo pred dogodki v Ukrajini, so bili precej kompleksni. Strateško okolje je bilo zelo dinamično in nepredvidljivo, od premika moči z zahoda na vzhod, usmerjanja ZDA na azijsko-pacifiško območje, finančne krize, varnostnih izzivov, ki so sledili arabski pomladi, do zaključevanja operacije Isaf (Brattberg, 2013, str. 19-20). Dogodki v Ukrajini so spremenili predpostavke pri zagotavljanju evropske varnosti, postavili $\mathrm{v}$ ospredje kolektivno obrambo in utrdili čezatlantske vezi. Zavezništvo se je s številnimi ukrepi varnostnih zagotovil enoglasno odzvalo na zaprosila svojih vzhodnih članic. Temu primerno bo obarvana tudi agenda vrhunskega srečanja Nata, ki bo od 4. do 5. septembra 2014 v Walesu v Veliki Britaniji.

Osrednja tema vrha bo Prihodnji Nato. Posega na vsa prej omenjena področja, od krepitve čezatlantske vezi in partnerstev, zagotavljanja ustreznih virov za obrambo, razvoja zmogljivosti, večjega števila usposabljanj in vaj, do nove zavezniške misije v Afganistanu in pregleda odnosov z Rusijo. V novih okoliščinah bo vsekakor več pozornosti namenjene kolektivni obrambi, premeščanju in nameščanju zavezniških sil znotraj meja zavezništva, intenzivnosti vojaških vaj in scenarijem visoke stopnje intenzivnosti ter odzivnosti sil, predvsem NRF (GS Nata, 26. marec 2014, Vershbow, 1. maj 2014, in Vershbow, 13. maj 2014).

Prihodnost Nata bo zaznamoval tudi prihod novega generalnega sekretarja 1. oktobra 2014. Zaveznice so na to funkcijo imenovale nekdanjega norveškega predsednika vlade Jensa Stoltenberga, ki ga spremljajo zgodovina uspešnih pogajanj z Rusijo, obdobje rasti norveških obrambnih izdatkov in transformacija njihovih obrambnih sil $\mathrm{v}$ visoko intenzivne in premostljive zmogljivosti, pozivi Nata, da se usmeri na varnostne izzive blizu zavezniškemu ozemlju, močno zagovarjanje čezatlantskega sodelovanja, vključno s pozivi za pravičnejšo delitev bremen, ter zavzemanje za komplementarnost Nata in EU pri zagotavljanju evropske in širše varnosti (Nato, 28. marec 2014).

\subsection{Prihodnost čezatlantske vezi}

V premisleku o prihodnosti čezatlantske vezi, hrbtenice zavezništva, moramo upoštevati dinamiko zadnjih nekaj let. Pri tem se lahko opremo na pisanje Howortha (2013, str. 33 - 34), ki izpostavlja tri elemente, ki so v zadnjih letih zaznamovali držo ZDA. Prvi je bil razviden iz Natove operacije Združen zaščitnik v Libiji, v kateri 
so ZDA prevzele vlogo vodenja od zadaj, medtem ko so bile evropske zaveznice v ospredju, s čimer so ZDA vsaj na simbolni ravni pokazale, da so pripravljene prepustiti odgovornost na evropskem prizorišču Evropi. Drugi element je bil govor obrambnega sekretarja Gatesa junija 2011, ${ }^{6}$ v katerem je zelo neposredno posvaril evropske zaveznice, da morajo okrepiti svoje napore in prevzeti večjo odgovornost znotraj zavezništva, če želijo ohraniti močno čezatlantsko vez. Tretji element so Strateške smernice, sprejete januarja $2012,{ }^{7}$ ki so najavile preusmeritev ZDA na azijsko-pacifiško območje. ${ }^{8}$

Med najbolj izpostavljenimi oziroma spornimi področji med zaveznicami ostajajo obrambni izdatki. Kot smo omenjali že v poglavju o virih, ZDA namenjajo za obrambne izdatke več kot štiri odstotke BDP, medtem ko je večina drugih zaveznic daleč od dveh odstotkov. Izvršilna oblast v Washingtonu se spopada z okrepljenimi pritiski svoje legislature (kongresa) po zmanjševanju obrambnih izdatkov in $\mathrm{z}$ učinkovitejšim prepričevanjem svojih evropskih zaveznic, da zmanjšajo ta razkorak. Ob spremenjenem varnostnem okolju, ko se občutek nevarnosti povečuje prav na vzhodu stare celine, je v ameriških očeh še toliko bolj izpostavljena potreba, da Evropa pokaže in dokaže, da je pripravljena nositi svoj delež bremena (Pifer, 2014).

V luči svoje spremenjene drže in kompleksnega varnostnega okolja bodo ZDA v prihodnje potrebovale preprosto več pomoči partnerjev in zaveznic (Obama, 28. maj 2014). Preneseno to pomeni, da naj se Evropa dokončno pomakne od uporabnika varnosti do proizvajalca varnosti. Trdna čezatlantska vez za prihodnost je odvisna tudi od vojaške moči Evrope (Brattberg, 2013, str. 20-21, in Coelmont in Langlois, 2013). Mogoče je bilo nekoč mišljeno, da bo Evropa prevzela večji del bremena tudi v širšem geografskem smislu (Azija, Afrika), vendar se to, kot kaže, v bližnji prihodnosti ne bo zgodilo, saj se vrača potreba po ustreznih in zadostnih silah za delovanje na domači celini.

Pritiski ZDA, naj Evropa prevzame večji del bremena, so se pojavljali že nekaj časa, vendar zaradi finančnih omejitev, s katerimi se je Evropa spoprijemala, in pomanjkanja občutka ogroženosti niso naleteli na plodna tla. Šele z izbruhom nedavne ruskoukrajinsko krize je prišlo do potrebne podlage, ki lahko vodi v spremenjeno držo evropskih zaveznic, $\mathrm{z}$ ustreznim ustvarjanjem politične volje in podpore prebivalstva za zagotavljanje investicij v varnost in obrambo, tako v Natu kot EU. Seveda to prepričanje na celini ni enotno in prinaša tudi nevarnost novih delitev, ki so se ob preliminarnih razpravah, predvsem o prihodnosti odnosov z Rusijo, že pokazale.

\footnotetext{
Gates, Robert. The Security and Defence Agenda: The Future of NATO. Govor obrambnega sekretarja, 10. junij 2011. http://www.defense.gov/speeches/speech.aspx?speechid=1581, 25. maj 2014.

DoD. Sustaining U.S. Global Leadership, Priorities for 21st Century Defence. Januar 2012. http://www. defense.gov/news/defense_strategic_guidance.pdf, 25. maj 2014.

8 Podobno tudi Larrabee in drugi, 2012, str. $99-101$.
} 


\subsection{Odnosi z Rusijo}

Medtem ko se krepi čezatlantska vez, ${ }^{9}$ bodo odnosi z Rusijo verjetno doživeli nekaj sprememb, vendar sta njihova obseg in globina odvisna predvsem od reševanja aktualne krize v Ukrajini. Uresničevanje strateškega partnerstva med Natom in Rusijo, kot so ga zaveznice določile v Strateškem konceptu, je v sedanjih razmerah nepredstavljivo (no busines as usual). Po ruskih akcijah v Ukrajini se je v večini zavezniških prestolnic izgubilo zaupanje in vse zaveznice so tudi obsodile rusko kršitev mednarodnega prava. Ponekod so šle stvari še precej dlje, saj so se spet pojavili stari strahovi, ki na obzorju že vidijo obrise ruskih tankov. Kljub vsem spremembam varnostnih ocen mora zavezništvo situacijo ocenjevati trezno in premišljeno. Rusija meji na Nato in ostaja ključen akter pri zagotavljanju evroatlantske in tudi širše globalne varnosti. Nato bo tudi s sedanjimi oblastniki v Kremlju moral poiskati modus vivendi, seveda pa ne na račun kompromisov o zavezniški varnosti. Ponovitev preteklosti, neke vrste mini hladna vojna, ne bi v tem trenutku koristila nikomur, razen posameznim nostalgikom na obeh straneh, ki nikoli niso sprejeli dejstva, da je za nekatere tako predvidljivi bipolarni svet razpadel.

Sklep Za Nato je obdobje po letu 2014 predvsem priložnost, da potrdi in okrepi svojo vlogo garanta evropske varnosti in stabilnosti v širšem prostoru. Za ohranjanje kredibilnosti ne bo dovolj samo izpopolnjevati tega, kar smo že naredili, temveč predvsem uresničiti, kar smo si obljubili. Žal ne bo zasluženega predaha po vročini Afganistana, temveč bo treba okrepiti napore v smeri, ki smo jo skupaj in tako daljnovidno začrtali na vrhunskem srečanju v Lizboni s sprejetjem Strateškega koncepta. Kateri so tisti strateški izzivi, ki lahko ogrozijo našo pot? Njihovi obrisi so jasni in noben ni posebna novost. Vsi so med seboj nekako povezani in lahko jih poenostavimo s trojno osjo med razpoložljivimi viri, robustnostjo in vzdržljivostjo čezatlantske vezi ter skupno oceno grožnje oziroma njenega zaznavanja. V odsotnosti občutka ogroženosti denarja ne bo. Ali je ukrajinska kriza zadostna spodbuda za vse članice, da opravijo nujne spremembe v svojih proračunih, je prav tako vprašljivo. $\mathrm{Na}$ podlagi zadnjih znakov so se hitro odzvale le tiste članice, ki so bile že tako v ospredju prepoznavanja krize kot začetka nove hladne vojne. Tudi tistim, ki jim ukrajinska kriza ne jemlje spanca, bi moralo biti jasno, da so pred Evropo resne varnostne grožnje. Sirija še naprej gori, islamski ekstremizem divja po ulicah Iraka in prve posledice morije v Levantu so že potrkale na vrata evropskih prestolnic. Nadaljevanje pomanjkanja evropskih sredstev verjetno pomeni upad navdušenja v Washingtonu za vzdrževanje neravnovesja v zmogljivostih in tako posledično krhanje čezatlantske vezi. Seveda ameriške prisotnosti v Evropi oziroma njihovega obrambnega proračuna ne vodi altruizem, temveč predvsem ameriški nacionalni interesi. Kljub temu pa je verodostojnejši evropski pristop k plačevanju skupnega obrambnega računa pomemben dokaz prepričanja političnih elit na obeh straneh

\footnotetext{
Krepitev čezatlantske vezi se kaže tudi v naslanjanju, predvsem vzhodnih zaveznic, na zmogljivosti ZDA kot prvi odgovor na krizo v Ukrajini. V ozračju, ki nekatere spominja na hladno vojno, sta bila tako nekajdnevna obiska ameriškega predsednika Obame v Evropi marca in junija 2014 namenjena podajanju in prepričljivosti varnostnih zagotovil ter prenašanju sporočila, da ZDA kljub najavljeni usmerjenosti na azijsko-pacifiško regijo Evropi ne bodo obrnile hrbta (Obama, 26. marec 2014 b, Obama, 3. junij 2014 a, in Obama 3. junij 2014 b).
} 
Atlantika, da smo v tem čolnu skupaj in da smo vsi plačali karte. Seveda le, če želimo, da ZDA ostanejo v Evropi, kar pa je po naši oceni predpogoj za nadaljevanje takšnega Nata, kot bi si ga želeli in kot ga naši davkoplačevalci tudi zaslužijo. Moramo jih le še prepričati, da to tudi plačajo.

1. Appathurai, J., 2014. The Future of NATO Partnership. V Flockhart, Trine, ur., 2014. Cooperative Security: NATO's Partnership Policy in a Changing World. DIIS Report, str. 35-45. http://en.diis.dk/files/publications/Reports2014/WP2014-01_NATO-partnerships_ TFL_web.pdf, 25. 5. 2014.

2. Asmus, R. et al, 2010. NATO, new allies and reasurance. CER Policy Brief. http://www. nato.int/strategic-concept/pdf/CER\%20Reassurance\%20(May\%202010).pdf, 25. 5. 2014.

3. Brattberg, E., 2013. Europe, Afghanistan and the Transatlantic Relationship after 2014. Stockholm International Peace Research Institute. http://books.sipri.org/product_info?c_ product_id=461, 25. 5. 2014.

4. Coelmont, J., Langlois, M., 2013. Recalibrating CSDP-NATO Relations: The Real Pivot. IRSEM, Policy Brief No. 47. http://www.europarl.europa.eu/ meetdocs/2009_2014/documents/sede/dv/sede100713backgroundcoelmont_ SEDE100713BackgroundCoelmont_EN.pdf, 25. 5. 2014.

5. GS Nata, Anders Fogh Rasmussen, 1. 4. 2014. Izjava za medije, Bruselj. http://www.nato. int/cps/en/natolive/opinions_108511.htm, 25. 5. 2014.

6. Howorth, J., 26. 2. 2013. The EU and NATO After Libya and Afghanistan: The Future of Euro-U.S. Security Cooperation. Yale Journal of International Affairs. http://yalejournal. org/wp-content/uploads/2013/03/Howorth.pdf, 25. 5. 2014.

7. Kulesa, L., ur., december 2012. The Future of NATO's Deterrence and Defence Posture: Views from Central Europe. Report of the Polish Institute of International Affairs in Partnership with the Nuclear Security Project. http://www.pism.pl/publications/reports/ PISM-Report-The-Future-of-NATO-s-Deterrence-and-Defence-Posture-Views-fromCentral-Europe, 25. 5. 2014.

8. Lampret, U., Novak, S., 2010. Nov Strateški koncept Nata: Zakaj je Nato še vedno nepogrešljiv? V Bilten Slovenske vojske. November 2010, 12/št. 4, str. 15-31. Ljubljana, Generalstab Slovenske vojske. http://www.slovenskavojska.si/fileadmin/slovenska_vojska/ pdf'bilten_sv/bilten_sv_12_4.pdf, 25. 5. 2014.

9. Larrabee, S. F., 2012. NATO and the Challenges of Austerity. National Defence Research Institute. http://www.rand.org/content/dam/rand/pubs/monographs/2012/RAND_MG1196. pdf, 25. 5. 2014.

10. Münchenska varnostna konferenca, 2011, 2012 in 2013. https://www.securityconference. de/, 25. 5. 2014.

11. Nato, 24. 2. 2014. Financial and Economic Data Relating to NATO Defence, PR/ CP(2014)028. http://www.nato.int/nato_static/assets/pdf/pdf_topics/20140224_140224PR2014-028-Defence-exp.pdf, 25. 5. 2014.

12. Nato, 4. 3. 2014. The Consultation Process and Article 4. http://www.nato.int/cps/en/ natolive/topics 49187.htm, 29. 5. 2014.

13. Nato, 31. 3. 2014. Partnerships: A cooperative approach to security. http://www.nato.int/ cps/en/natolive/topics_84336.htm, 29.5.2014.

14. Nato, 24. 10. 2013. The Connected Forces Initiative.

15. http://www.nato.int/cps/en/natolive/topics_98527.htm, 29. 5. 2014.

16. Nato, 1. 4. 2014. NATO takes measures to reinforce collective defence, agrees on support for Ukraine. http://www.nato.int/cps/en/natolive/news_108508.htm, 29. 5. 2014. 
17. Nato, 3. 6. 2014 a. Doorstep statement by NATO Secretary General Anders Fogh Rasmussen in advance of the meetings of NATO Defence Ministers. http://www.nato.int/ cps/en/natolive/opinions_110615.htm, 4. 6. 2014.

18. Nato, 3. 6. 2014 b. NATO steps up collective defense, support to reforms in Ukraine. http://www.nato.int/cps/en/natolive/news_110609.htm, 4. 6. 2014.

19. Nato, 7. 8. 2014. NATO and Cyber Defence. http://www.nato.int/cps/en/natolive/ topics_78170.htm?, 10.8. 2014.

20. NSC Magazine. Junij/september 2014, št. 11, str. 4-17. Intervju z GS Nata, The reformer takes stock and looks ahead. NATO Staff Centre.

21. Obama, Barack, 26. 3. 2014 a. Remarks by the President in Address to European Youth, Bruselj. http://www.whitehouse.gov/the-press-office/2014/03/26/remarks-presidentaddress-european-youth, 25. 5. 2014.

22. Obama, Barack, 26. 3. 2014 b. Tiskovna konferenca, Bruselj. http://www.whitehouse. gov/the-press-office/2014/03/26/press-conference-president-obama-european-councilpresident-van-rompuy-a, 25. 5. 2014

23. Obama, Barack, 28. 5. 2014. Remarks by the President at the United States Military Academy Commencement Ceremony, Vojaška akademija ZDA West Point. http://www. whitehouse.gov/the-press-office/2014/05/28/remarks-president-west-point-academycommencement-ceremony, 29. 5. 2014.

24. Obama, Barack, 3. 6. 2014 a. Remarks by President Obama Before a Meeting with Central and Eastern European Leaders. Varšava, Poljska. http://www.whitehouse.gov/thepress-office/2014/06/03/remarks-president-obama-meeting-central-and-eastern-europeanleaders, 29. 5. 2014.

25. Obama, Barack, 3. 6. 2014 b. Remarks by President Obama and President Komorowski of Poland in a Joint Press Conference. Varšava, Poljska. http://www.whitehouse.gov/ the-press-office/2014/06/03/remarks-president-obama-and-president-komorowski-polandjoint-press-conf, 29. 5. 2014

26. Pifer, S., 2014. NATO looks divided and its eastern members look exposed. Financial Times, 20. 5. 2014, str. 9. http://www.ft.com/cms/s/0/510f3ef6-dd20-11e3-854600144feabdc0.html\#axzz32iOiYCFL, 20. 5. 2014.

27. Polat, S., NATO ACT, 6. 4. 2014. NATO Reform at the Glance. http://www.act.nato.int/ article-2014-1-19, 29. 5. 2014.

28. SACEUR gen. Philip M. Breedlove, 22. 5. 2014. Uvodni nagovor na novinarski konferenci po 171. srečanju načelnikov generalštabov Nata. http://www.nato.int/cps/en/natolive/ opinions_110223.htm?selectedLocale=en, 25. 5. 2014.

29. Zavezniško združeno poveljstvo sil Brunssum, 27. 5. 2014. NATO Reassurance Measures in response to Crisis in Ukraine. http://www.jfcbs.nato.int/jfcbrunssum/news archive/2014/nato-reassurance-measures-ukraine-crisis.aspx, 29. 5. 2014.

\section{Natovi dokumenti}

1. Deklaracija o obrambnih zmogljivostih iz Chicaga, ki so jo sprejeli vodje držav in vlad na zasedanju Severnoatlantskega sveta v Chicagu 20. 5. 2012. http://www.nato.int/cps/en/ natolive/official_texts_17120.htm.

2. Deklaracija iz Lizbone, ki so jo sprejeli vodje držav in vlad na zasedanju.

3. Severnoatlantskega sveta v Lizboni. 20. 11. 2010. http://www.nato.int/cps/en/natolive/ official_texts_17120.htm.

4. Severnoatlantski sporazum, sklenjen v Washingtonu, podpisan 4. 4. 1949, velja od 24. 8 . 1949. http://www.nato.int/cps/en/natolive/official_texts_17120.htm.

5. Strateški koncept Nata, ki so ga sprejeli vodje držav in vlad na zasedanju Severnoatlantskega sveta v Lizboni, 2010. 